\title{
Barthelme's Vision of the Postmodern Society in His Short-Fiction
}

Granit Zela

\author{
Lecturer, Foreign Language Center, Armed Forces Academy \\ Training and Doctrine Command, Tirana, Albania \\ E-mail: zelagranit401@gmail.com
}

\section{Doi:10.5901/jesr.2013.v3n7p620}

\begin{abstract}
The paper examines short stories of the distinguished American postmodernist writer Donald Barthelme that make an assessment of the concept of the society by creating a world that reveals his vision of the society. Many of Barthelme's shortstories describe the social fabric that holds them together including the buying and selling of luxurious items, services, and even other human beings within an affluent, amoral social set, whose insatiable desire for travel, novelty, and escape also functions as a form of play. An appraisal of the world defined by the short stories "To London and Rome" "City Life", and "Perpetua" reveals Barthelme's vision of the contemporary postmodern society. Development of this theme in these individual stories in which it appears constitutes one of the Barthelme's achievements in literature.
\end{abstract}

Keywords: American Literature, Barthelme, short-fiction, vision of the society.

\section{Object of Study and Literature Review}

This paper wil have at its main object of sudy the vision of the society in some of the short-stories of the American PostModernist writer Donald Barthelme (1931-1989). The short stories examines some his short stories which are considered in the context of the reflection of postmodernist society by attempting to shed light on this theme in the short fiction of this distinguished writer.

Barthelme's short stories were collected in Come Back, Doctor Caligari (1964), Unspeakable Practises, Unnatural Acts (1968), City Life (1970), Sadness (1972), Amateurs (1976), Great Days (1979), Sixty Stories (1981), Overnight to Many Distant Cities (1983), Forty Stories (1987), The Teachings of Don B. (posthumously in 1992) short-story collections that constitute the primary source of reference of this study.

In these collections he deals with consumerism (To London and Rome; Concerning the Bodyguard), politics (Robert Kennedy Saved from Drowning; The President, Belief), war (A Picture of the History of the War; Engineer-Private Paul Klee), fatherhood invoking a metaphor of power, the relationship between the past and present and past and present forms of art (A Shower of Gold; The Agreement) (McCaffery 1986: 267) and many other themes.

In this paper we focus on the theme of society as a theme that permeates many of his short stories and constitutes one of the most relevant achievements in literature. Athough the short stories dealing with the social fabric of the modern life are numerous and include short-stories such as "To London and Rome", "I Bought a Little City", "The Captured Woman", "Will you tell me?" "Edward and Pia", "Moments of Waking and Sleeping", "Perpetua", "Critique de la vie Quotidienne", "The Party", "City Life", "The Indian Uprising", "Paraguay" etc.

A typical Barthelme story shatters what Wayne Stengel (Stengel 1985:20), calls" the morass of modern life," salvages the pieces, and regroups them in ways that may entertain and promote critical reflection on their origin. This paper has as its object of study only three of them, considered as the most representative:

1. "To London and Rome" included in the short story collection, Come Back, Dr. Caligari. Boston 1964.

2. "Perpetua", part of the short-story collection Sadness. New York, 1972.

3. "City Life" in Barthelme's collection, Sixty Stories. New York: Penguin, 1993.

An appraisal of the world defined by these short stories reveals Barthelme's vision of the contemporary postmodern society.

\section{The horror coming from the hollowness of the society}

To London and Rome describes two protagonists, Peter and Alison, a married couple, who try to evade the sterility of 
their relationship by using money to place themselves above their boredom and inability to communicate. Their ludicrously hedonistic lives thus form a social orbit of their own devising. Such play suggests activities commonly associated with a child's play: ceaseless restlessness and a desire for new pursuits and simulations to avert boredom. Barthelme envisions a marriage whose partners base all their social actions on this concept of play. Peter and Alison, physical adults but emotional children, play with life by buying their way through it. Money fuels and propels their lives; it supplies the means by which they entertain themselves, avoid monotony, and remain insulated from the silences that engulf their relationship. (Stengel 1985:159)

The society depicted in To London and Rome, included in Come Back Dr, Kaligari (1964) parodies the flatness and terror of Harold Pinters' theater of menace and presents a thoroughly a debased world. "To London and Rome" becomes a morality tale because of its total lack of moral and humane concerns. The Necchi sewing machine that its protagonist buys his wife and Rolls Royce that he uses to impress his mistress both have more life and more motivation than any of this story's characters. "To London and Rome" forms a rigorously mechanistic society, which manufactures perfect models of its world's nightmarish imperfections. In this society the myth of acquisition as fulfillment has made purchase a device for momentary release from other desires. "To London and Rome" serves as an apt title for a society constantly in motion, searching for stimulation that can always be bought but seemingly never enjoyed.

The technique of To London and Rome gives the story a consistently imaginative sense of humor and play. Barthelme tells the story in a series of unpunctuated dialogues between Peter, Alison and their assorted serfs and underlings. In a narrow column running down the left- hand margin of the page, he inserts playwrights' directions which tell the reader either how to interpret a particular conversation or what occurs before or after the current speaker's comment. These marginalia sometimes constitute responses to the conversations. In this left-hand column, Barthelme prints all the long, short, frightened, or comic silences preceding and following conversations that make To London and Rome a parody of Pinteresque theater of absurd.

The materials of To London and Rome have conscious affinities with the emotionally sparse, laconic worlds of Pinter and Samuel Beckett, even though those writers often deal with the impoverished and the dispossessed, whereas Barthelme's subjects more frequently are affluent and the overindulged. But though these writers instill their vision of the society in their techniques, their styles reflecting a tense, anguished world, Barthelme makes his material selfconsciously thin and then superimposes on it a prosaic vernacular style.

Barthelme's technical approach to the story consciously raises the question: if growing numbers of individuals form their only links with society or make their only connections with other human beings by buying and selling, how does innovative literature convey this reality without appearing to be simply refurbished absurdist drama? The column down the left-hand side of the page in To London and Rome forms a dialogue with the story proper and answers this question. In reasserting that the silences between the empty prattle represent actual silences, that these fictional people have countless vacuous counterparts in reality, the story recognizes that this society's decline taxes the descriptive powers of language. The story accomplishes a difficult task with a technique that consistently playfully amuses.

The hollowness of this society, its incessant urge to play, and the relationship between these qualities are mirrored in the story's humorous silences and pauses in its opening paragraphs. In To London and Rome Barthelme creates a world so uniformly one-dimensional that any single detail becomes as important as any other. The story becomes absurdist theater in prose and creates a vision of society as lifeless as much absurdist drama. Whatever values Peter's world contains, it lacks a sense of morality. Therefore danger exists in misreading To London and Rome and other technically innovative Barthelme society stories. These tales do not function merely as popular explorations of contemporary cultures that refuse to judge their findings.

In the visually and typographically interesting story To London and Rome Barthelme places the "narrative" on the right side of the page and a gloss on the left. "To London..." is a satire on contemporary marriage, about people who accumulate things to assure themselves they are alive. Their purchases, starting with a Necchi sewing machine and including a mistress, a big house, a piano, a Rolls Royce, a race horse, and finally a hospital that treats horses and Viscout jets, is an exercise in pataphysics. The story, in addition, is filled with "pauses" in the gloss which, unlike Pinter's famous pauses (which are always a mask for terror beneath), emphasize the empty silence of the typically respectable, affluent couple, and they, the pauses, are really the subject of the story. The horror we feel in reading this comes from our locating meaning only in the lines and pauses, in the absence of anything beneath.(Lois Gordon 1985:58)

Barthelme's initial efforts to redesign plot's architecture with spatial patterns are sometimes labored and selfconscious. An early collage experiment, To London and Rome renders plot into simultaneous narratives. Claiming almost three fourth of each page's textual space, the story proper catalogs Peter and Alison's obsessive purchasing and jokes toward a conclusion as rapidly as Peter can write checks. Conversely, in the page's narrow left-hand columns idle all the 
pauses, intervals, and silences that might delay the contrived plot. Frustrating the reader's habitual left-to-right march across the page, the story generates horizontal, vertical, and diagonal cross-references. (Barbara L.Roe 1992:31).

Shortly after Alison and Peter buy a concert grand piano in the story proper, for instance, they discuss calling a piano instructor, learn they are overdrawn at the bank, and then leave for breakfast. Peter also ignores Alison's come hither-look. In the left-hand column, however, lurk a silence thick with sex, the couple's interlude in bed, and phone calls ordering a piano teacher and a piano tuner. If the reader disregards the narrative on the left to follow the predominant story, he misses not only the sex scene, but also the phone calls (Alison and Peter miss out as well). Consequently, when two mysterious strangers later appear unannounced in the living room on the right, the reader must back-track, take a diagonal leap to the left-hand margin, and mentally collate his findings in order to verify the intruder's identities.

With such heavy-handed, comic disruptions, Barthelme offers several possibilities for superimposing the alternative stories, but the process suffers limits, since, "To London and Rome" still relies on plot to mesh its narrative parts. A tire various yokes, belts, or shackles a goat. We note the anomaly and pass on. Certainly, more provocative displacements occur when Barthelme minimizes linear sequence to diddle verb tense, tone, speech patterns, and point of view. As he refines these prismatic designs, he borrows other artist's advantages too. (Barbara L. Roe 1992:31.)

This story is tour de force in linguistic virtuosity, where, although syntax and sentence structure remain traditional, meaning is continuously challenged and widened by juxtapositions of odd, banal, literary, or technical diction; at other points, ordinary language is violated by bizarre and fragmented action. Space and time maybe dislocated to reinforce the distortions of traditional language or narrative pattern. Identities merge; banality and horror are interchangeable; everything is equally meaningful and hence meaningless. Specifically, everyone is everyone's else's lover, child, threat and even nemesis. (Lois Gordon 1985:40)

\section{The chaotic contemporary city}

The story Perpetua, follows the exploits of a woman who attempts to make a society in her own image but finds instead a modern urban world composed of hundreds of thousands of individuals just like herself. Perpetua asks how spontaneity or individuality can ever survive in a society that automatically processes and merchandises those traits. The story focuses on the contemporary chaotic city as a place of refugee for its protagonist, who suddenly becomes bored with the routine and monotony of conventional married life. Quickly fascinated by the self-consciously new or distinctive, Perpetua enters the contemporary city, a world that reflects the transience of the modern life.

Attempting escape, distraction, and a surrogate existence, she constantly dresses her old self in instantly dated fashions. Moreover, the story implies that the trash formed from yesterday's refuse has taken on a life and value of its own, which society does not understand and cannot completely control. The voguishness of the city reduces much human activity to mere imitation. Perpetua, now living alone equates like Ramona and Elsa in "City Life" oiling her trumpet with finding a lover. A consumer who has bought the sell that the variety is the spice of life, i.e., one must have a post-divorce fling-she says: "Now I must obtain a lover...Perhaps more than one. One for Monday. One for Tuesday. One for Wednesday."

Although to the reader, her life is one would not call uneventful, to Perpetua nothing has the least consequence, she plays the trumpet with the New World Symphony, smokes dope with a bassoon player, discusses art and revolution, and sleeps with a variety of men, after "cruising around" to find them. She remains isolated from her son, who calls her only for money and really prefers the company of his snake collection. At Christmas she visits her mother, who this year will be cooking "the eighty seventh turkey of her life." Harold, her ex-husband, watches television, visits his son in boarding school, and devotes himself to tracking down some model (jn fact, a friend of Perpetua's) who posed nude for a girlie magazine. The bleakness of their prospects is reminiscent of "Critique" underscored by the muted dialogue at the conclusion when they meet once again: "I just want to ask you one question," Harold said. "Are you happier now then you were ever before?" "Sure," Perpetua said. (Lois Gordon 1985:126)

This city is a labyrinth full of cul-de-sacs and unmarked doors form which professional eccentrics emerge. All its social relationships have a random and coincidental quality. Its citizens meet. Make love, and part as casually as pedestrians jostle one another in its streets at rush hour. These people seem like cardboard cutouts rather than three dimensional human beings, and their affairs and experiences can only be lifeless and brittle. By duplicating the gestures and styles of all those around her, Perpetua fails to realize that originality cannot be reproduced. Her story develops as a repetitive fable, which demonstrates that a satisfying society must be created from the ground up. Using the rubbish of her new world to escape the debris of her past, Perpetua quickly becomes trapped in the city's fads and clichés. 


\section{Searching a human vision in an inhumane civilization}

The title of the story "City Life" sketches the humdrum existence of Ramona and Elsa, who have just moved into an apartment. Once again, everything in their world is equally significant-career, sexual partner, where to hang curtains and place the phone book. That life has lost its priorities is epitomized in Ramona's explanation of her Immaculate Conception pregnancy- a result, it would appear, of the subhuman isolation of urban life, if not the existential conditions. The Virgin Ramona has been impregnated by the indifference, absurdity, and sludge of the modern life. (Barbara L. Roe 1992:31.)

By contrast, "City Life" evolving through an investigation of the creative process, shows how creativity and the individual human imagination can be sharpened by constant contact with an urban environment. Ramona, a New Yorker and the protagonist of the story, gives birth to a child she fully believes has been conceived without sexual intercourse. The popular rock singer Moonbelly writes a song to commemorate his birth, entitled "Cities are Centers of Copulation." After Moonbelly receives a gold record for selling a million copies of the song, Ramona imagines channeling the collective energy of the New York City so that all nine million residents would refuse to pay their inflated electricity bills.

In this eccentric manner, "City Life" records the interrelationships between the individual human consciousness and the artistic process, which the city as a high voltage charge inspiring both qualities. Unlike Perpetua, Ramona finds a place where she can accept diverse lives. For Ramona, the city as a society becomes an enormous field of energy. She interprets her creative responsibility as finding a means of focusing this energy to influence artistic potential in those around her. Through her artistry and Moonbelly's she discovers that her urban society functions as a vast collage of possibilities for the creation of everything from pop art to her highly suspect announcement of a second virgin birth. In the endless, claustrophobic clash of citizen with citizen in this society, a huge array of signs, sign language, and sign systems undergoes continual transformation.

Naturally, this society has dangers. When its signs overwhelm their human receptors, the city becomes a jungle. The individual creative consciousness must control or regulate these signs or they will control the individual. At its most philosophical, "City Life" denies that city, as such, exists. The city, Ramona contends represents nothing more than the conscious attitudes of all its residents toward it. Thus Ramona finds the city the ideal place for the consciousness to create art. The art can host the eternal, imaginative tension between the men and the women, tradition and originality, rage and vitality, form and content.

"City Life" accomplishes what none of the other society stories mentioned above does. It imagines a livable world and then offers the ingredients from which an artistic sensibility might compose such a society. It presents a theory not only of society but of art and creativity as well. The story contends that though art rises from the tensions between an urban society and its residents, the role of the artist is ultimately to shape her own art and her own imaginative world. Though art presumes an affinity of feeling between the creator and audience, the canny artist shapes the rules and expectations by which her imagined society lives so that her public experiences the social vision she wishes to evoke. Reciprocically, the greatest art may even change the society it attempts to reflect.

Accordingly, Barthelme's art comprises both affirmations of Moonbelly's "Cities are Centers of Copulation" and Ramona's belief that her child was conceived without sexual contact. Yet because his art remains strongly committed to the integrity of his individual human consciousness, however original or perverse his views, it must frequently be at odds with the society.(Wayne Stengel 1985:162)

\section{Conclusions}

Barthelme's art has a moral function beyond specific social concerns. Above all, his art stands beyond empirical knowledge. Containing mystical or intuitive elements, his artistic process can be telepathic. Thus, Barthelme's concept of society rests in the eye and the consciousness of his artists. Not only in "City Life" but in "To London and Rome," and "Perpetua," the artist are individuals who attempt to create a society in their own images. Only in "City Life" however, does Barthelme create a society in which his protagonist can live happily while aiding, and not manipulating, her fellow human beings. City Life questions whether any artist can create and affirm a human vision from the garbage of a trashed civilization. It leaves the solution to the spirited consciousness of a maverick like Ramona in "City life." Therefore, of all the stories analyzed in this paper, only "City Life" offers hope from the creation of a productive, energized society.

The characters of these stories seem emotionless, fickle men and women attempting to escape the knowledge of their own wasteland while simultaneously fascinated with its debris these people are in flight from themselves. From the voracious society of these stories take the reader to more cities and locations around the globe but again depicts modern 
society as restless, self-obsessed and confused in the horror coming from the hollowness of the society, the chaos of the contemporary city and the search of a human vision in a inhumane civilization.

\section{References}

Barthelme, Donald Come Back, Dr. Caligari. Boston: Little, Brown, 1964.

Barthelme, Donald Sixty Stories. New York: Penguin, 1993. 144-59.

Barthelme Donald, Sadness. New York: Farrar, Straus and Giroux, 1972.

Gordon, Lois, Donald Barthelme, Twayne's United States Authors series, Boston: G. K. Hall, 1985.

McCaffery, Larry. The Metafictional Muse: The Works of Robert Coover, Donald Barthelme, and William H. Gass. Pittsburgh: Universioty of Pittsburgh P, 1982.

Roe, Barbara L. Donald Barthelme: A study of the short-fiction, Twayne Publishers, New York, 1992.

Stengel, Wayne, The Shape of Art in the Short Stories of Donald Barthelme, Louisiana State University Press, Baton Rouge and London, 1985. 